О.В. Харченко ${ }^{1}$, С.В. Пащенко ${ }^{1}$, С.В. Кубарь ${ }^{1}$, Ю.В. Коцуренко ${ }^{1}$

${ }^{1}$ Державний науково-дослідний інститут авіації, Київ

\title{
МОЖЛИВІ ШЛЯХИ ПОСТАЧАННЯ ВЕРТОЛЬОТІВ ДЛЯ ПОТРЕБ МОРСЬКОЇ АВІАЦІЇ ВІЙСЬКОВО-МОРСЬКИХ СИЛ ЗБРОЙНИХ СИЛ УКРАЇНИ ТА ЇХ ТЕХНІЧНИЙ ОБРИС
}

\begin{abstract}
У статті авторами, на основі аналізу стану парку літальних апаратів морської авіації та основних завдань Військово-Морських Сил Збройних Сил України, визначено, щэо одним із пріоритетних напрямів розвитку морської авіації $\epsilon$ оновлення вертолітного парку. Визначено можливі шляхи постачання вертольотів для потреб морської авіаиії Військово-Морських Сил Збройних Сил Украӥни з використанням існуючого науково-методичного апарату. Проведено аналіз основних тактико-технічних характеристик сучасних іноземних зразків морських вертольотів, за результатами якого, з урахуванням можливостей вітчизняних підприємств промисловості, сформовано технічний обрис вертольотів для потреб морської aвiaųiï.
\end{abstract}

Ключові слова: морська авіація, вертоліт, тактико-технічні характеристики, технічний обрис.

Вступ

Постановка проблеми. Стратегія ВійськовоМорських Сил (ВМС) Збройних Сил (3С) України передбачає до 2035 року три етапи розвитку, на кожному з яких, враховуючи нагальні виклики та завдання, визначено конкретні пріоритети спроможностей усіх родів ВМС, у тому числі і морської авіації [1; 2, с. 38...40].

Розвиток морської авіації як компоненти ВМС ЗС України та набуття необхідних спроможностей $\epsilon$ актуальним питанням, виходячи із завдань, які на неї будуть покладатися, а саме: виконання завдання протичовнової, протиповітряної, протикатерної оборони, ведення розвідки, спостереження за обстановкою, підтримання морських десантних, пошуково-рятувальних, специфічних дій на воді [1].

На сьогодні у складі морської авіації на озброєнні перебувають транспортні літаки типу Ан-2 та Ан-26, пошуково-рятувальні та протичовнові літаки-амфібіі Бе-12ПС (ПЛ), протичовнові вертольоти типу Ка-27ПЛ й Ми-14ПЛ, пошуковорятувальні Ка-27ПС та Ми-14ПС, транспортнобойові вертольоти типу Ка-29, вертольоти типу Ми-2МСБ та Мі-8МСБ-В, Ми-8ИВ й Ми-8СМВ, багатоцільовий вертоліт Ка-226. Наразі до бойового складу також введено розвідувально-ударний безпілотний авіаційний комплекс Bayraktar TB2. Основними завданнями вказаних типів літальних апаратів $\epsilon$ [3; 4, с. 7]: ведення повітряної розвідки, викриття надводної та підводної обстановки; пошук, стеження та знищення підводних човнів противника; пошуково-рятувальне забезпечення дій сил в морі; виконання транспортних повітряних перевезень; здійснення повітряної вогневої підтримки дій військ (сил).

Аналіз стану вертолітного парку, як найбільш чисельної складової, морської авіації ВМС ЗС України свідчить, що основними проблемними питаннями, які потребують вирішення, є досягнення граничних строків служби більшістю штатних вертольотів, необхідність освоєння заводського ремонту вертольотів типу Ка-27 і Ка-29 на підприємствах Державного концерну “Укроборонпром", створення необхідного ремонтного фонду запасних частин та комплектуючих, а також невідповідність бойових можливостей штатних протичовнових вертольотів вимогам сьогодення.

Такий стан обумовлює актуальність здійснення заходів щодо відновлення справності та льотної придатності існуючого парку вертольотів, їх модернізації у напрямку розширення бойових можливостей та поліпшення експлуатаційних характеристик, а також закупівлі нових сучасних вертольотів.

Аналіз останніх досліджень і публікацій. Питанню розвитку та набуття необхідних спроможностей ВМС ЗС України, у тому числі і морської авіації, присвячена певна кількість наукових публікацій, зокрема $[2$, с. $38 \ldots 40 ; 5$, с. 14 ; $6 ; 7$, с. 76...78]. У них розглядаються такі можливі варіанти забезпечення необхідного рівня спроможностей морського озброєння і військової техніки: перший - виробництво в Україні; другий закупівля за кордоном; третій - комбінований. 
Крім того в [7, с. 76] повідомлено, що в інтересах розвитку спроможностей морської авіації планується створити та закупити морські патрульні літаки та провести модернізацію вертольотів.

У зазначених публікаціях відсутня більш повна інформація щодо можливих варіантів та технічного обрису перспективних морських вертольотів, а також щодо науково-методичного апарату, який може бути використаний для вибору раціонального варіанту з можливих за обраним критерієм.

Мета статті. На основі аналізу основних тактико-технічних характеристик сучасних іноземних зразків морських вертольотів та основних завдань ВМС ЗС України сформувати технічний обрис вертольотів для потреб морської авіації 3 урахуванням можливостей вітчизняних підприємств промисловості.

\section{Виклад основного матеріалу}

Можливими шляхами (альтернативними проєктами) оснащення морської авіації ВМС 3С України перспективними вертольотами доцільно розглядати:

власне або спільне виробництво (розроблення вертольотів та організація їх серійного виробництва силами національних підприємств із залученням іноземних компаній для постачання складових / комплектуючих, які не виробляються в Україні);

міжнародну кооперацію (участь у міжнародній програмі створення вертольотів 3 максимальним залученням потенціалу національних підприємств); ліцензійне виробництво (придбання ліцензії та організація ліцензійного виробництва (збирання) вертольотів на території України);

закупівлю вертольотів за імпортом;

оренду (лізинг) вертольотів у закордонного партнера.

Вибір раціональних шляхів переозброєння вертолітного парку морської авіації ВМС ЗС України $\epsilon$ складною науково-прикладною проблемою, яка може бути вирішена за допомогою методико-алгоритмічного апарату вибору раціональних проєктів 3 оснащення ЗС України перспективними літальними апаратами [8, с. 39...44]. Вказаний науково-методичний апарат включає часткові методики оцінювання відповідності літальних апаратів прийнятим оперативнотактичним вимогам [9, с. 80], реалізованості проєктів [10, с. 24...29], військово-технічного рівня літальних апаратів [11], вартості реалізації проєктів та часу їх реалізації $[8$, с. 41], формування області ефективних (парето-оптимальних) проєктів та вибору 3 них раціональних (рис. 1).

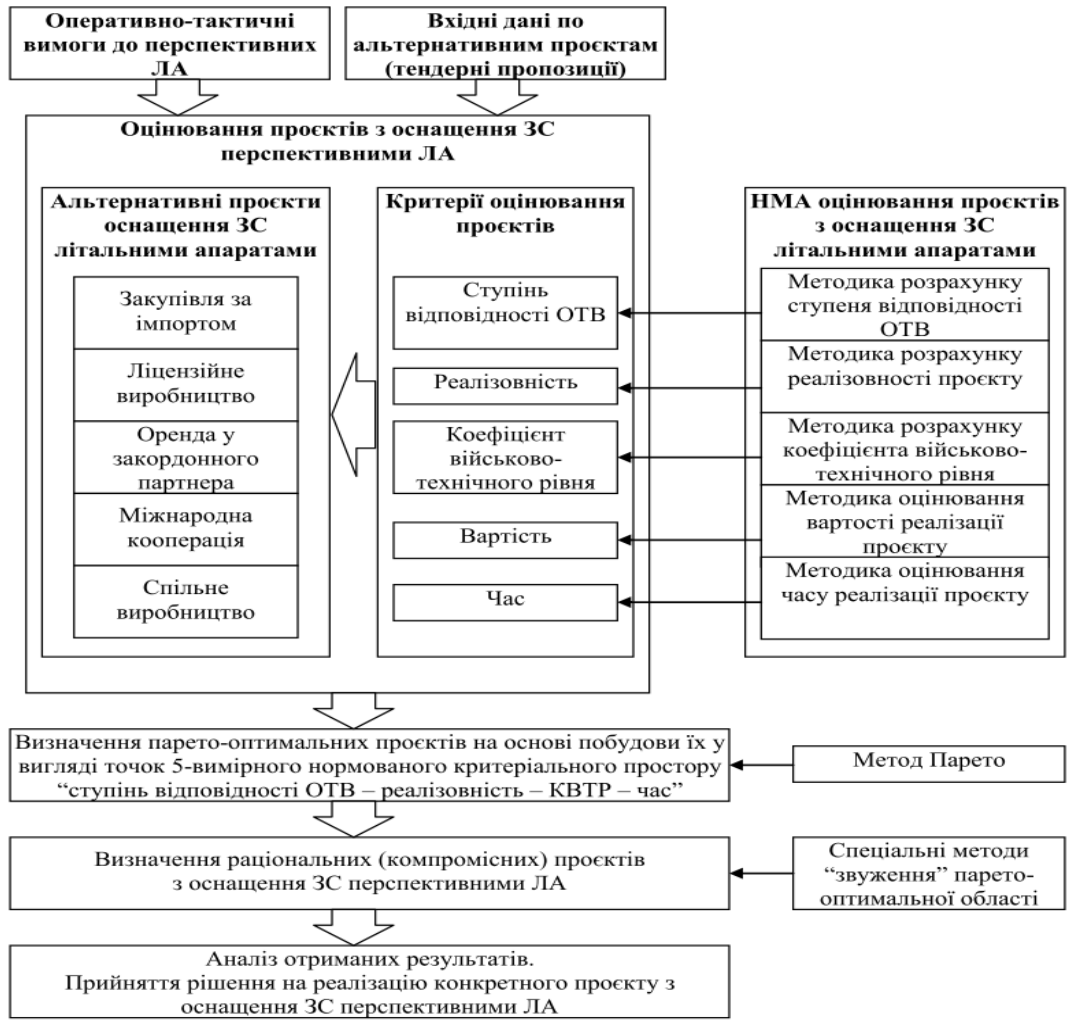

Рис. 1. Структурна блок-схема узагальненої методики оцінювання ефективності проєктів з оснащення Збройних Сил України перспективними літальними апаратами.

Джерело: [8, с. 40]. 
Одним iз найважливіших показників (критеріїв), за яким може здійснюватися оцінювання ефективності альтернативних проєктів оснащення морської авіації перспективними вертольотами $\epsilon$ вартість реалізації проєкту (вартість життєвого циклу). На сьогодні відомі різні підходи до оцінювання вартості життєвого циклу зразків озброєння та військової техніки [8, с. 41; 12 , с. 46...50; 13], тому в Міністерстві оборони України розроблено Методику розрахунку вартості життєвого циклу зразків озброєння та військової техніки, яка після затвердження може застосовуватись у науковометодичному апараті [8, с. $39 \ldots 44]$.
На сьогодні типаж вертольотів морської авіації розвинених держав зазвичай включає протичовнові, пошуково-рятувальні та транспортно-бойові (багатофункціональні) вертольоти $[14$, с. 26...38, c. $49 . .96]$.

До протичовнових вертольотів, які добре зарекомендували себе під час виконання бойових завдань і досі перебувають на озброєнні морської авіації армій світу, належать вертольоти (таблиця 1):

AB 212 ASW (Італія, 1976 рік); S-70B-6 (США, 1979 рік); AS565 Panther (Франція, 1984 рік); Super Lynx (Великобританія, 1990 рік).

Основні характеристики сучасних іноземних протичовнових вертольотів

\begin{tabular}{|c|c|c|c|c|}
\hline Найменування характеристики & AB.212ASW & S-70B-6 & AS.565 Panther & $\begin{array}{c}\text { Super Lynx HMA } \\
\text { Mk.8 }\end{array}$ \\
\hline Базування & $\begin{array}{c}\text { Корабельне і } \\
\text { наземне }\end{array}$ & $\begin{array}{c}\text { Корабельне i } \\
\text { наземне }\end{array}$ & $\begin{array}{c}\text { Корабельне i } \\
\text { наземне }\end{array}$ & $\begin{array}{c}\text { Корабельне i } \\
\text { наземне }\end{array}$ \\
\hline Екіпаж, чол. & $\begin{array}{l}2 \text { льотчика i } \\
2 \text { оператора }\end{array}$ & $\begin{array}{l}2 \text { льотчика і } \\
1 \text { борттехнік }\end{array}$ & $1 ; 2$ & $\begin{array}{l}2 \text { льотчика i } \\
2 \text { оператора }\end{array}$ \\
\hline Діаметр несучого гвинта, м & 14,63 & 16,36 & 11,94 & 12,80 \\
\hline Довжина, м & 17,40 & 19,76 & 13,68 & 11,92 \\
\hline Висота, м & 4,53 & 5,13 & 3,97 & 3,67 \\
\hline Максимальна злітна маса, кг & 5070 & 11113 & 4300 & 5330 \\
\hline Тип і кількість двигунів & $\begin{array}{c}1 \times \Gamma \text { ТД } \\
\text { Pratt \& Whitney } \\
\text { PТ-6T-3 } \\
\end{array}$ & $\begin{array}{c}2 \times \Gamma \text { Т } \\
\text { General Electric } \\
\text { T700-GE-701C }\end{array}$ & $\begin{array}{c}2 \times \Gamma \text { Т } \\
\text { Turbomeca } \\
\text { Arriel IM1 }\end{array}$ & $\begin{array}{c}2 \times \text { ГТД } \\
\text { Rolls-Royce } \\
\text { Gem Mk.42-1 } \\
\end{array}$ \\
\hline Енергоозброєнність, кВт/кг & 0,275 & 0,252 & 0,271 & 0,313 \\
\hline Потужність двигунів, кВт & $1 \times 1398$ & $2 \times 1402$ & $2 \times 584$ & $2 \times 835$ \\
\hline Максимальна швидкість, км/год & 240 & 296 & 296 & 282 \\
\hline Крейсерська швидкість, км/год & 200 & 282 & 278 & 232 \\
\hline Швидкопідйомність, м/хв & 532 & 472 & 420 & 661 \\
\hline Практична статична стеля, м & 3200 & 2330 & 2600 & 2275 \\
\hline Практична динамічна стеля, м & 4550 & 5835 & 4300 & 5500 \\
\hline Практична дальність, км & 667 & 584 & 875 & 1047 \\
\hline $\begin{array}{l}\text { Корисне навантаження: } \\
\text { на зовнішній підвісці / в кабіні }\end{array}$ & \begin{tabular}{|c|}
2270 кг вантажу / - \\
7 солдат або \\
4 нош i \\
1 медпрацівник \\
\end{tabular} & $\begin{array}{c}4082 \text { кг вантажу / } \\
1197 \text { кг вантажу; } \\
11 \text { солдат або } 6 \text { нош }\end{array}$ & $\begin{array}{c}-/ 1700 \text { кг } \\
\text { вантажу; } \\
10 \text { солдат }\end{array}$ & $\begin{array}{c}1360 \text { кг вантажу / } \\
907 \text { кг вантажу; } \\
9 \text { солдат }\end{array}$ \\
\hline $\begin{array}{l}\text { Габарити вантажної кабіни, м: } \\
\text { довжина×ширина×висота }\end{array}$ & $2,34 \times 2,31 \times 1,245$ & $4,95 \times 2,21 \times 1,87$ & $2,3 \times 1,92 \times 1,16$ & $2,06 \times 1,78 \times 1,42$ \\
\hline Об'єм вантажної кабіни, м ${ }^{3}$ & 6,73 & 20,45 & 5,00 & 5,21 \\
\hline Кількість вузлів підвіски & 2 & 4 & 2 & 2 \\
\hline Максимальна маса озброєння, кг & 490 & 4536 & - & 726 кг \\
\hline
\end{tabular}

Джерело: розроблено авторами за даними [14...17].

Аналіз основних характеристик зазначених вертольотів дозволяє констатувати:

усі вертольоти забезпечують корабельне і наземне базування;

вертоліт AS565 Panther має удвічі менший склад екіпажу, ніж інші;

усі вертольоти мають близькі геометричні розміри, за виключенням вертольота S-70B-6, який на $10 \ldots 25 \%$ більший за інші;

за максимальною злітною масою усі вертольоти практично однакові, за виключенням вертольота S-70B-6, який більш, ніж удвічі важчий, за інші; усі вертольоти оснащені двома газотурбінними двигунами, за виключенням вертольота AB.212ASW, який має один двигун; енергоозброєність вертольота Super Lynx на $10 . .15 \%$ вища, ніж у інших;

максимальна i крейсерська швидкості усіх вертольотів практично однакові;

максимальна швидкопідйомність вертольота Super Lynx на 20...35 \% вища, ніж у інших;

практична статична і практична динамічна стелі усіх вертольотів відрізняються у невеликих межах; 
найбільшу практичну дальність має вертоліт Super Lynx, яка на 15...45 \% більша, ніж у інших;

найбільшу масу вантажу у кабіні може перевозити вертоліт AS565 Panther, інші - майже удвічі меншу;

найбільшу масу вантажу на зовнішній підвісці може перевозити вертоліт S-70B-6, інші - у 2...3 рази меншу;

кількість особового складу, що перевозиться на всіх вертольотах, відрізняється у невеликих межах, але людей на ношах можуть перевозити лише вертольоти AB.212ASW i S-70B-6;

найбільший об'єм вантажної кабіни має вертоліт S-70B-6, інші - практично у 4 рази менший;

найбільшу кількість вузлів підвіски озброєння має вертоліт S-70B-6, інші - у 2 рази меншу;

найбільшу максимальну масу озброєння може перевозити вертоліт S-70B-6, інші - у 6..10 разів меншу;

усі вертольоти оснащені стрілецько-гарматним озброєнням, протичовновими торпедами, керованими ракетами класу “повітря - повітря” та “повітря - поверхня”, протитанковими керованими ракетами, протикорабельними керованими ракетами, некерованими авіаційними ракетами та глибинними бомбами, що забезпечують ефективне ураження різноманітних цілей відповідно до призначення вертольотів;

усі вертольоти мають бортове обладнання, що забезпечує їх бойове застосування по передбаченим цілям, у тому числі вдень і вночі, у складних метеорологічних умовах і при наявності хвиль, а також в умовах протидії противника (пошукові радіолокаційні станції, гідроакустичні системи, магнітометри, оптико-електронні системи, радіогідроакустичні буї, автоматичні системи стабілізації, автопілот);

конструкція усіх вертольотів забезпечує їх живучість при базуванні на кораблях, а також в умовах протидії противника.

Таким чином, серед наведених протичовнових вертольотів певна перевага належить вертольотам Super Lynx i S-70B-6.

Найбільш відомими і поширеними у світі на сьогодні $є$ такі пошуково-рятувальні вертольоти (таблиця 2):

Таблиця 2

Основні характеристики сучасних іноземних пошуково-рятувальних вертольотів

\begin{tabular}{|c|c|c|c|c|}
\hline Найменування характеристики & $\begin{array}{l}\text { AS.565MA } \\
\text { Panther }\end{array}$ & $\begin{array}{l}\text { AW.101/EH.101 } \\
\text { Merlin }\end{array}$ & AW.139 & $\begin{array}{l}\text { H.225 Super } \\
\text { Puma }\end{array}$ \\
\hline Базування: корабельне / наземне & $+/+$ & $+/+$ & $+/+$ & $+1+$ \\
\hline Екіпаж, чол. & $1 ; 2$ & $\begin{array}{l}2 \text { льотчика i } \\
2 \text { оператора }\end{array}$ & $1 ; 2$ & 2 \\
\hline Діаметр несучого гвинта, м & 11,94 & 18,59 & 13,80 & 16,20 \\
\hline Довжина, м & 13,68 & 22,80 & 16,65 & 19,50 \\
\hline Висота, м & 3,97 & 6,62 & 4,95 & 4,97 \\
\hline Максимальна злітна маса, кг & 4300 & 14600 & 6400 & 11200 \\
\hline Тип і кількість двигунів & $\begin{array}{c}2 \times \Gamma \text { ТД } \\
\text { Turbomeca } \\
\text { Arriel IM1 }\end{array}$ & $\begin{array}{c}3 \times \Gamma \text { ТД } \\
\text { Rolls- } \\
\text { Royce Turbomeca } \\
\text { RTM322-01/08 }\end{array}$ & $\begin{array}{c}2 \times \text { ГТД } \\
\text { Pratt Whitney } \\
\text { Canada PТ6C-67C }\end{array}$ & $\begin{array}{c}2 \times \Gamma \text { ТД } \\
\text { Turbomeca } \\
\text { Makila 2A1 }\end{array}$ \\
\hline Енергоозброєнність, кВт/кг & 0,271 & 0,321 & 0,401 & 0,317 \\
\hline Потужність двигунів, кВт & $2 \times 584$ & $3 \times 1566$ & $2 \times 1286$ & $2 \times 1776$ \\
\hline Максимальна швидкість, км/год & 296 & 309 & 310 & 275 \\
\hline Крейсерська швидкість, км/год & 278 & 286 & 278 & 260 \\
\hline Швидкопідйомність, м/хв & 420 & 612 & 600 & 522 \\
\hline Практична статична стеля, м & 2600 & 4575 & 3600 & 2770 \\
\hline Практична динамічна стеля, м & 4300 & 6500 & 5843 & 6035 \\
\hline Практична дальність, км & 875 & 1129 & 1061 & 1135 \\
\hline $\begin{array}{l}\text { Корисне навантаження: } \\
\text { на зовнішній підвісці / в кабіні }\end{array}$ & $\begin{array}{c}-/ 1700 \text { кг } \\
\text { вантажу; } \\
10 \text { солдат }\end{array}$ & $\begin{array}{c}3732 \text { кг вантажу / } \\
3100 \text { кг вантажу; } \\
30 \text { солдат } \\
\text { або } 16 \text { нош }\end{array}$ & $\begin{array}{c}2700 \text { кг вантажу / } \\
2500 \text { кг вантажу; } \\
15 \text { солдат або } \\
6 \text { нош і } 4 \text { санітари }\end{array}$ & $\begin{array}{c}-/ 6 \text { солдат або } \\
12 \text { нош i } \\
4 \text { санітари }\end{array}$ \\
\hline $\begin{array}{l}\text { Габарити вантажної кабіни, м: } \\
\text { довжина×ширина×висота }\end{array}$ & $2,3 \times 1,92 \times 1,16$ & $7,09 \times 2,49 \times 1,64$ & $2,70 \times 2,10 \times 1,42$ & $7,87 \times 1,8 \times 1,45$ \\
\hline Об'єм вантажної кабіни, м ${ }^{3}$ & 5,00 & 29,00 & 8,05 & 15,0 \\
\hline Кількість вузлів підвіски & 2 & $2 \ldots 4$ & - & 2 \\
\hline Максимальна маса озброєння, кг & - & 960 & - & - \\
\hline
\end{tabular}

Джерело: розроблено авторами за даними $[14,15]$ 
AW101/EH101 Merlin (Великобританія, Італія, 2000 рік);

AW139 (Великобританія, Італія, 2003 рік);

H225 (Airbus Helicopters, 2004 рік).

Аналіз основних характеристик зазначених вертольотів дозволяє констатувати:

усі вертольоти забезпечують корабельне і наземне базування;

вертоліт AW101/EH101 Merlin має удвічі більший склад екіпажу, ніж інші;

вертольоти AW101/EH101 Merlin i Н225 мають геометричні розміри більші, ніж у інших вертольотів на $25 \ldots 35 \%$;

за максимальною злітною масою вертольоти AW101/EH101 Merlin і Н225 більше, ніж у 2 рази важчі за інші;

усі вертольоти оснащені двома газотурбінними двигунами, за виключенням вертольота AW101/EH101 Merlin, який має 3 двигуни;

енергоозброєнність вертольота AW139 на 20 \% вища, ніж у вертольотів AW101/EH101 Merlin i H225, і на $35 \%$ - ніж у вертольота AS565MA Panther;

максимальна i крейсерська швидкості усіх вертольотів практично однакові;

максимальна

швидкопідйомність

вертольотів AW101/EH101 Merlin i AW139 на

$15 . .30 \%$ вища, ніж у інших;

практична статична i практична динамічна стелі вертольота AW101/EH101 Merlin вищі, ніж у інших на $10 \ldots 30 \%$;

практична дальність у більшості вертольотів практично однакова, за виключенням вертольота AS565MA Panther, у якого вона на 20 \% менша;

найбільшу масу вантажу у кабіні може перевозити вертоліт AW101/EH101 Merlin, інші поступаються йому на $20 \ldots 45 \%$;

найбільшу масу вантажу на зовнішній підвісці може перевозити, також, вертоліт AW101/ЕН101 Merlin;

найбільшу кількість особового складу, що перевозиться, може здійснювати вертоліт AW101/EH101 Merlin, інші - поступаються йому у 2...3 рази;

найбільший об'єм вантажної кабіни має вертоліт AW101/EH101 Merlin, інші - мають у $2 . .6$ разів менший;

найбільшу кількість вузлів підвіски озброєння має вертоліт S-70B-6, інші - у 2 рази меншу;

вертольоти AW101/EH101 Merlin i H225 оснащені авіаційними засобами ураження, що забезпечують ураження широкої номенклатури морських цілей (стрілецько-гарматне озброєння, некеровані авіаційні ракети, протикорабельні ракети, протичовнові торпеди та глибинні бомби);

усі вертольоти мають бортове обладнання, що забезпечує виконання поставлених завдань відповідно до призначення, у тому числі вдень і вночі, у складних метеорологічних умовах і при наявності хвиль, а також в умовах протидії противника (пошукові радіолокаційні станції, гідроакустичні системи, магнітометри, оптикоелектронні системи, радіогідроакустичні буї, автоматичні системи стабілізації, автопілот);

конструкція усіх вертольотів забезпечує їх живучість при базуванні на кораблях, а також в умовах протидії противника.

Таким чином, серед наведених протичовнових вертольотів у цілому перевага належить вертольотам AW101/EH101 Merlin i H225.

До сучасних i поширених транспортнобойових (багатоцільових) вертольотів належать (таблиця 3):

S-92IU (США, 2004 рік);

NH90NFH (Великобританія, Італія, ФРН, Франція, Нідерланди, 2006 рік);

AW159 Wildcat (Великобританія, Італія, 2014 рік).

Аналіз основних характеристик зазначених вертольотів дозволяє констатувати:

усі вертольоти забезпечують корабельне і наземне базування;

вертоліт NH90NFH має удвічі більший склад екіпажу, ніж інші;

вертоліт AW159 Wildcat має геометричні розміри менші, ніж у інших вертольотів на $20 \ldots .25 \%$;

за максимальною злітною масою вертоліт AW159 Wildcat майже у 2 рази легший за інші;

усі вертольоти оснащені двома газотурбінними двигунами i мають практично однакову енергоозброєність;

максимальна i крейсерська швидкості, максимальна швидкопідйомність, а також практична статична i практична динамічна стелі усіх вертольотів приблизно однакові;

найбільшу практичну дальність має вертоліт NH90NFH, інші - поступаються на $10 . .20 \%$;

найбільшу масу вантажу у кабіні може перевозити вертоліт S-92IU, NH90 NFH поступається йому на $40 \%$;

найбільшу масу вантажу на зовнішній підвісці може перевозити, також, вертоліт S-92IU, а NH90 $\mathrm{NFH}$ - поступається йому майже у 6 разів; 
найбільшу кількість особового складу, що перевозиться, можуть здійснювати вертольоти S-92IU i NH90 NFH, а вертоліт AW159 Wildcat менше у 3 рази; вертольоти S-92IU i NH90 NFH мають практично однаковий об'єм вантажної кабіни;

Основні характеристики сучасних іноземних транспортно-бойових вертольотів

\begin{tabular}{|c|c|c|c|}
\hline Найменування характеристики & S-92IU & NH.90 NFH & AW.159 Wildcat \\
\hline Базування & $\begin{array}{c}\text { Корабельне i } \\
\text { наземне }\end{array}$ & $\begin{array}{c}\text { Корабельне i } \\
\text { наземне }\end{array}$ & $\begin{array}{c}\text { Корабельне i } \\
\text { наземне }\end{array}$ \\
\hline Екіпаж, чол. & 2 & $1-4$ & 2 \\
\hline Діаметр несучого гвинта, м & 17,71 & 16,30 & 12,80 \\
\hline Довжина, м & 17,31 & 15,89 & 15,24 \\
\hline Висота, м & 6,45 & 5,44 & 3,73 \\
\hline Максимальна злітна маса, кг & 12020 & 10000 & 6250 \\
\hline Тип і кількість двигунів & $\begin{array}{l}2 \times \Gamma \text { Т General } \\
\text { Electric СТ7-8A }\end{array}$ & $\begin{array}{c}2 \times \Gamma \text { ТД Rolls- } \\
\text { Royce/Turbomeca } \\
\text { RTM 322-01/9 }\end{array}$ & $\begin{array}{l}2 \times \text { ГТД LHTEC } \\
\text { CTS800-4N }\end{array}$ \\
\hline Енергоозброєнність, кВт/кг & 0,380 & 0,338 & 0,324 \\
\hline Потужність двигунів, кВт & $2 \times 1879$ & $2 \times 1690$ & $2 \times 1015$ \\
\hline Максимальна швидкість, км/год & 306 & 300 & 311 \\
\hline Крейсерська швидкість, км/год & 280 & 262 & 275 \\
\hline Швидкопідіймальність, м/хв & - & 660 & 600 \\
\hline Практична статична стеля, м & 3000 & 2600 & 2362 \\
\hline Практична динамічна стеля, м & 4575 & 4250 & 4570 \\
\hline Практична дальність, км & 945 & 1150 & 777 \\
\hline $\begin{array}{l}\text { Корисне навантаження } \\
\text { на зовнішній підвісці / в кабіні }\end{array}$ & $\begin{array}{c}4536 \text { кг вантажу / } \\
4200 \text { кг вантажу; } \\
24 \text { солдата } \\
\text { або } 16 \text { нош }\end{array}$ & $\begin{array}{c}700 \text { кг вантажу / } \\
2500 \text { кг вантажу; } \\
14-20 \text { солдат } \\
\text { або } 12 \text { нош }\end{array}$ & -/7 солдат \\
\hline $\begin{array}{l}\text { Габарити вантажної кабіни, м: } \\
\text { довжина×ширина×висота }\end{array}$ & $5,66 \times 2,01 \times 1,83$ & $4,8 \times 2,0 \times 1,58$ & - \\
\hline Об'єм вантажної кабіни, м & 16,88 & 18,00 & - \\
\hline Максимальна маса озброєння, кг & - & 700 & - \\
\hline
\end{tabular}

Джерело: розроблено авторами за даними [14...16].

вертольоти оснащені авіаційними засобами ураження, що забезпечують ураження заданих цілей відповідно до призначення (стрілецько-гарматне озброєння, некеровані авіаційні й протикорабельні ракети, протичовнові торпеди та глибинні бомби);

вертольоти мають бортове обладнання, що забезпечує виконання поставлених завдань відповідно до призначення, у тому числі вдень і вночі, у складних метеорологічних умовах і при наявності хвиль, а також в умовах протидії противника (пошукові радіолокаційні станції, гідроакустичні системи, магнітометри, оптикоелектронні системи, радіогідроакустичні буї, автоматичні системи стабілізації, автопілот);

конструкція усіх вертольотів забезпечує їх живучість при базуванні на кораблях, а також в умовах протидії противника.

Отже, серед наведених протичовнових вертольотів певна перевага належить вертольотам S-92IU i NH90 NFH.
Разом 3 тим, як свідчить аналіз фінансової сторони контрактів на постачання вище вказаних типів вертольотів [14], вартість такої складової контрактної ціни, як “обладнання та послуги" досягає до 50 \% від загальної вартості контракту.

Це, насамперед, характерно в тих випадках, коли закуповуються вертольоти, які раніше не експлуатувалися у країні-імпортері, що потребує створення нової або адаптації існуючої інфраструктури, систем обслуговування та ремонту, підготовки особового складу, логістичного забезпечення тощо.

У категорії “обладнання та послуги" основними складовими $є$ витрати на закупівлю боєкомплектів (протитанкових керованих ракет, некерованих авіаційних ракет, керованих ракет класу “повітря - повітря" та “повітря - поверхня", авіаційних торпед, протикорабельних ракет, снарядів авіаційних гармат та ін.), установок авіаційного озброєння (блоків, перехідних балок, пускових пристроїв тощо), авіаційних тренажерних 
комплексів наземного базування, засобів експлуатації та наземного обслуговування, наземних засобів радіотехнічного забезпечення польотів, комплектів запасних частин і матеріалів, технічної (експлуатаційної, ремонтної) документації та ін.

Разом 3 тим, на сьогодні, крім виконання заходів 3 підтримання справності вертолітного парку морської авіації, до його складу постачаються модернізовані Публічним акціонерним товариством “МОТОР СІЧ” та прийняті на озброєння ЗС України вертольоти типу Ми-2МСБ та Мі-8МСБ-В, розширення спроможностей та покращення характеристик яких в подальшому можливе шляхом встановлення додаткового обладнання та виконання відповідних робіт за бюлетенями промисловості або в рамках дослідно-конструкторських робіт 3 їх модернізації.

Крім того, в інтересах ВМС ЗС України в рамках виконання дослідно-конструкторської роботи 3 розроблення вертольоту МСБ-2Н додатково до базового варіанту передбачено розроблення вертольотів пошуково-рятувального та морського патрульного корабельного базування.

Розроблення та постачання цих вертольотів для потреб морської авіації забезпечить виконання завдань: пошуку, відстеження й ураження підводних човнів у підводному i надводному положеннях; ведення повітряної розвідки; пошуку, відстеження та наведення на корабельні сили противника та видачі цілевказання; вогневої підтримки дій сил (військ) Військово-Морських Сил Збройних Сил України; рятування або надання допомоги екіпажам морських і повітряних суден, що зазнають лиха.

При цьому, на основі аналізу складу бортового обладнання сучасних морських вертольотів іноземного виробництва, можна сформувати основні вимоги до складу бортового обладнання морського пошуково-рятувального вертольота та морського патрульного (протичовнового) вертольота корабельного базування [18, с. 82].

До складу бортового обладнання морського пошуково-рятувального вертольота берегового базування повинні входити:

гіростабілізована оптико-електронна станція; пошуковий прожектор;

рятувальна лебідка;

пошукова радіолокаційна станція; радіолокаційна гідроакустична станція 3 комплектом гідроакустичних буїв;

полозкове шасі;

система аварійного приводнювання (балонети). До складу бортового обладнання морського патрульного (протичовнового) вертольота корабельного базування додатково повинні входити:

системи автопілотування та автоматичної посадки на палубу корабля;

система складання лопатей;

спеціальне обладнання для пошуку, виявлення надводних і підводних цілей;

система швартування для забезпечення можливості використання на палубі корабля;

система озброєння для ураження надводних i підводних цілей.

\section{Висновки}

В найближчій перспективі актуальним $\epsilon$ здійснення заходів щодо відновлення справності та льотної придатності існуючого парку вертольотів, закупівлі вертольотів типу Ми-2МСБ та Мі-8МСБ-В 3 виконанням робіт щодо встановлення додаткового обладнання за бюлетенями промисловості i модернізації у напрямку розширення бойових можливостей та поліпшення експлуатаційних характеристик.

В подальшому 3 метою набуття необхідних спроможностей морської авіації ВМС ЗС України доцільним $\epsilon$ виконання заходів 3 поступового переозброєння вертолітного парку на нові типи морських вертольотів шляхом закупівлі сучасних вертольотів вітчизняного або іноземного виробництва.

За результатами порівняльного аналізу основних тактико-технічних характеристик сучасних протичовнових, пошуково-рятувальних та транспортно-бойових (багатофункціональних) вертольотів визначено найкращі типи іноземних вертольотів: серед протичовнових - Super Lynx i S-70B-6; серед пошуково-рятувальних AW101/EH101 Merlin i H225; серед транспортнобойових (багатофункціональних) - S-92IU i NH90 NFH.

На сьогодні існуючий науково-методичний апарат дозволяє здійснювати порівняльні оцінювання ефективності альтернативних проєктів оснащення морської авіації перспективними вертольотами та визначати найбільш раціональні за визначеними критеріями.

\section{Список літератури}

1. Стратегія Військово-Морських Сил Збройних Сил України 2035 [Електронний ресурс] // Військово-Морські Сили Збройних Сил України. - Режим доступу: https://navy.mil.gov.ua/strategiya-vijskovo-morskyh-syl-zbrojnyh-syl-ukrayiny-2035. 
2. Неїжпапа О.Л. Проблемні питання та перспективи розвитку Військово-Морських Сил Збройних Сил України / О.Л. Неїжпапа, А.А. Тарасов, С.В. Яким'як // Наука і оборона. - 2021 - № 3. - С. 36-40.

3. Військово-Морські Сили Збройних Сил України [Електронний ресурс] // Міністерство оборони України. Режим доступу: https://www.mil.gov.ua/ministry/sklad-zbrojnix-sil-ukraini/vijskovo-morski-sili.

4. 15 фактів про Військово-Морські Сили Збройних Сил України // Оборонний вісник. - 2021. - № 6. - С. 4-10.

5. Яким'як С.В. Стратегія безпеки на морі: сучасність і перспективи // Оборонний вісник. - 2021. - № 6. - С. 11-17.

6. Воєнні аспекти протидії “гібридній” агресії: досвід України: монографія / колектив авторів; за заг. ред. А.М. Сиротенка. - К.: НУОУ ім. Івана Черняховського, 2020. - 176 с.

7. Морська стратегія держави. Розвиток та реалізація морського потенціалу України: матеріали міжнародного наукового форуму, 19-20 травня 2021 року. - К.: НУОУ ім. Івана Черняховського, 2021 - 204 с.

8. Пащенко С.В. Методичне забезпечення вибору раціональних шляхів оснащення Збройних Сил України перспективними літальними апаратами / Пащенко С.В., Кубарь С.В., Мавренков О.Є. // Зб. наук. праць. - К.: ДНДІА, 2019. - Вип. 15 (22). - С. 39-48.

9. Мавренков О.С. Методичні підходи до оцінювання ступеня відповідності літального апарата прийнятим оперативно-тактичним вимогам / Мавренков О.С., Улізько В.І. // Зб. наук. праць. - К.: ДНДІА, 2019. - Вип. 15 (22). C. $80-81$.

10. Мавренков О.С., Улізько В.І. До питання оцінювання реалізованості програмних заходів 3 технічного оснащення авіації Збройних Сил України // Зб. наук. праць. - К.: ДНДІА, 2012. - Вип. 8 (15). - С. 135-140.

11. Методика розрахунку коефіцієнта військово-технічного рівня тактичного бойового літака / Затверджено заступником Міністра оборони України, реєстр. № 10694/3 від 02.06.2016.

12. Павловський І.В. Науково-методичні підходи до аналізу воєнно-технічних і техніко-економічних аспектів життєвого циклу зразків озброєння та військової техніки / І.В. Павловський, І.Б. Чепков, В.К. Борохвостов, О.М. Рябець // Наука і оборона. - 2017. - № 2. - С. 43-51.

13. Теорія озброєння. Науково-технічні проблеми та завдання. Т. 6. Воєнно-економічний аналіз життєвого циклу озброєння та військової техніки: теоретико-методологічні засади: монографія / І.Б. Чепков, В.В. Зубарєв, В.К. Борохвостов [та ін.]. К.: ВД Дмитра Бураго, 2018. -475 с.

14. Мировая торговля оружием // Центр анализа мировой торговли оружием. -2020 . - № 3. -98 с.

15. Military Helicopter: The concise global industry guide. Annual handbook // IISSUE 30. April 2017. - $196 \mathrm{c}$.

16. Вертолеты производства США // Приложение к информационно-аналитическому сборнику "На крыле". Выпуск №3, 2011. - 100 с.

17. Вертолеты производства Франции // Приложение к информационно-аналитическому сборнику "На крыле". Выпуск №4, 2011. - 106 с.

18. Тараненко В.В. Основні вимоги до перспективного морського патрульного вертольота / Тараненко В.В., Коцуренко Ю.В. // Тези доповідей та виступів на Міжн. наук.-практич. конференції “Актуальні проблеми розвитку авіаційної техніки”, XVI Міжн. спеціалізована виставка “Зброя та безпека”, 15 -18 червня 2021 р. - Київ: ДНДІА. 2021. C. 82 .

\section{Відомості про авторів:}

\section{Харченко Олександр Володимирович}

доктор технічних наук

професор

Начальник Державного науково-дослідного

інституту авіації,

Київ, Україна

https://orcid.org/0000-0002-9972-5233

\section{Пащенко Сергій Валерійович}

кандидат технічних наук

доцент

заступник начальника Державного науково-дослідного інституту авіації з наукової роботи,

Київ, Україна

https://orcid.org/0000-0002-8513-2488

\section{Information about the authors:}

\section{Oleksandr Kharchenko}

Doctor of Technical Sciences

Professor

Chief of State Research

Institute of Aviation,

Kyiv, Ukraine

https://orcid.org/0000-0002-9972-5233

\section{Serhii Pashchenko}

Candidate of Technical Sciences

Associate Professor

Deputy Chief

of State Research Institute of Aviation,

Kyiv, Ukraine

https://orcid.org/0000-0002-8513-2488 


\section{Кубарь Сергій Володимирович}

кандидат технічних наук

старший науковий співробітник

начальник науково-дослідного управління

Державного науково-дослідного інституту авіації,

Київ, Україна

https://orcid.org/0000-0001-8165-7140

\section{Коцуренко Юрій Вікторович}

кандидат військових наук

доцент

провідний науковий співробітник

Державного науково-дослідного інституту авіації,

Київ, Україна

https://orcid.org/0000-0001-7807-7225

\section{Serhii Kubar}

Candidate of Technical Sciences

Senior Researcher

Head of Research Management

of State Research Institute of Aviation,

Kyiv, Ukraine

https://orcid.org/0000-0001-8165-7140

\section{Yurii Kotsurenko}

Candidate of Military Sciences

Associate Professor

Leading Researcher

of State Research Institute of Aviation,

Kyiv, Ukraine

https://orcid.org/0000-0001-7807-7225

\title{
POSSIBLE WAYS OF SUPPLYING HELICOPTERS FOR NEEDS NAVAL AIRCRAFT OF THE ARMED FORCES OF UKRAINE AND THEIR TECHNICAL DESIGN
}

\author{
O. Kharchenko, S. Pashchenko, S. Kubar, Y. Kotsurenko
}

The article, based on the analysis of the naval aviation fleet condition and the main tasks of the Navy of Ukraine, determined that one of the priority directions of the naval aviation development is renewal of the helicopter fleet. It has been established that the issue of development and acquisition of the necessary capabilities of the Navy of Ukraine, including naval aviation, is devoted to a certain number of scientific publications, but they lack more complete information on possible variants and technical outline of perspective maritime helicopters, as well as on scientific and methodical apparatus, which can be used to select a rational option from the possible criteria. In the article the authors consider possible ways of helicopters supply for the needs of the Navy of Ukraine within the use of the existing scientific and methodical apparatus. The comparative analysis of the main tactical and technical characteristics of modern foreign samples of anti-submarine, rescue and transport-combat (multifunctional) helicopters was carried out, according to the results of which the best types of foreign helicopters were determined. It is emphasized that the cost of such a component of the contract price as "equipment and services" reaches up to $50 \%$ of the total cost of the contract for the supply of foreign helicopters. This is especially typical in cases where helicopters are purchased, which have not been used in the importing country before, which requires the creation of new or adaptation of existing infrastructure, service and repair systems, personnel training, logistics, etc. On the basis of the analysis of the onboard equipment of modern naval helicopters of foreign production the basic requirements to the onboard equipment of maritime rescue and maritime patrol (anti-submarine) ship-based helicopter have been formed. According to the results of the researches the authors concluded that in the near future it is urgent to carry out measures on restoration of the efficiency and flight suitability of the existing fleet of helicopters, purchase of helicopters of type Mi-2MSB and Mi-8MSB-V with carrying out of works on installation of additional equipment on industrial bulletins and modernization in the direction of expansion of military capabilities and improvement of operational characteristics. In the future, in order to acquire the necessary capabilities by the Navy aviation of Ukraine, it is expedient to carry out measures on gradual re-equipment of the helicopter fleet to new types of maritime helicopters by purchasing modern helicopters of domestic or foreign production.

Key words: maritime aviation, helicopter, tactical and technical characteristics, technical design. 